\title{
Participation of International Organizations in UN Treaties
}

\section{Klabbers, Jan}

Oxford University Press

2019-09-11

Klabbers , J 2019 , Participation of International Organizations in UN Treaties . in S Chesterman , D M Malone \& S Villalpando (eds), The Oxford Handbook of United Nations

Treaties . Oxford University Press , Oxford , pp. 649-662 . https://doi.org/10.1093/law/9780190947842.003.0039

http://hdl.handle.net/10138/332081

https://doi.org/10.1093/law/9780190947842.003.0039

unspecified

acceptedVersion

Downloaded from Helda, University of Helsinki institutional repository.

This is an electronic reprint of the original article.

This reprint may differ from the original in pagination and typographic detail.

Please cite the original version. 
Participation of International Organizations in UN Treaties

Jan Klabbers ${ }^{1}$

\section{Introduction}

When international organizations were first set up, mostly in the latter third of the nineteenth century, little thought was given to how they might relate to each other. And little thought needed to be given: the working assumption was that each organization (then still typically referred to as 'union') would be responsible for its own specific tasks, and that those tasks would rarely, if at all, need to be harmonized with each other. Each union had its own function, and was set up by member states precisely to give effect to that function. ${ }^{2}$

This picture is no longer tenable, if it ever was, and the topic of relations between international organizations inter se has come to generate its own research agenda. One particular manifestation of relations involving several international organizations is that certain organizations are allowed to participate in the activities of others or under auspices of others, including in practices of treatymaking. This applies, in general form, to what are sometimes referred to as 'regional economic integration organizations'; in actual practice, there is really one entity that is generally considered to fit the bill, and that is the European Union (EU).

Treaty-making is not the only relevant arena, nor is it a particularly well-defined arena. There is, for instance, much cooperation going on involving international organizations under headings as diffuse as standard-setting, or even enforcement: this too can generate standards that may not formally amount to new treaty provisions, but may nonetheless exercise normative authority over international actors. The work of the Contact Group on Piracy off the Somali Coast, a loose network of international organizations, states, industry groups and others, might be taken as an example.

${ }^{1}$ Academy Professor (Martti Ahtisaari Chair), University of Helsinki.

2 The underlying theory is often referred to as 'functionalism'. For a theoretical critique, see Jan Klabbers, 'The EJIL Foreword: The Transformation of International Organizations Law', (2015) 26 European Journal of International Law, 9-82. 
This chapter is however largely devoted to a discussion of the legal issues provoked by the position of regional economic integration organizations with particular reference to the UN system, especially relating to the EU's participation in treaties concluded within the UN system. ${ }^{3}$ For, the EU's special position raises a number of intriguing and potentially complicated legal issues, many of them masking (or sublimating), as so often, highly controversial political issues. Such issues manifest themselves both within the UN - as a matter of UN law, one might be tempted to say - and within the EU, as a matter of EU law. In what follows, I will briefly address the reason(s) why these matters call for new techniques of law-making and procedure (section II) and sketch some conceptual issues (section III). Section IV will discuss some of the issues this raises within the EU - the EU being effectively the only entity to which this applies. Section V will shift the focus to the UN and related organizations (such as the FAO), and aims to provide a discussion of the sort of questions this provokes and how these, generally, receive their answer. Section VI concludes.

A search of the UN Treaty Series suggests that the EU, in its various incarnations (EEC, EC, EU, and including treaties to which also EU member states are parties) is a party to close to 1000 treaties (974). That is a respectable number: a bit more than Haiti (754), but less than Canada, India or the United States, all of whom are parties to more than 1000 treaties. ${ }^{4}$ Still excluded are treaties to which EU offspring are parties, such as those concluded by the European Investment Bank or the European Chemicals Agency. Moreover, the number does not reflect participation of the EU in practices that are held not to amount to formal treaties, nor in treaty practices that have not been registered with the UN.

\section{The Logic}

\footnotetext{
${ }^{3}$ Editorial note: I will steadfastly refer to the EU, also when addressing earlier incarnations (EEC, EC), unless the context demands differently. The Treaty on European Union shall be abbreviated as TEU, whereas TFEU stands for the more detailed (less 'constitutional') Treaty on the Functioning of the European Union. ${ }^{4}$ See https://treaties.un.org/pages/Home.aspx?clang=_en (visited 4 June 2018). It seems that 1000 is the maximum number of hits available when doing a search for treaty participants.
} 
The EU is, thus far, the only generally recognized specimen of 'regional economic integration organization'. There is no single authoritative international definition available of the term ${ }^{5}$, but given that the EU is usually regarded as the only example, it is not unlikely that would-be regional economic integration organizations should take on some or all of the characteristics of the EU: set up by sovereign states, who have conferred sovereign authority and competences on common institutions in economic matters to take decisions or enter into agreements binding those same sovereign states. ${ }^{6}$ In other words, one key element would seem to be the possibility of binding the member states, and this entails that few organizations qualify. It is not excluded, of course, than in the future other organizations take on similar characteristics, although with the emergence of trade wars and new protectionism in the first half of 2018 , it is unlikely that this will happen any time soon.

Hence, while this contribution aims to address generally the position of international organizations, including regional economic integration organizations, the practical examples will be derived from the role and experiences of the EU. In this light, it may be useful briefly to sketch the EU setup: the EU experience is bound to be repeated or mimicked if other regional economic integration organizations will be created.

When the EU was originally established, in the 1950s, one of the ambitions behind what was at the time the European Economic Community (EEC) was that, after a transitional period of some twelve years, by 1970, certain competences would exclusively rest upon the EEC. This made instrumental sense: given the idea that the EEC should be a common market, it would need a common tariff at its external borders; such a common tariff, in turn, implied a common commercial policy; and this, in turn, implied that the six member states (as they

\footnotetext{
${ }^{5}$ Nor is it likely that there could be a single authoritative definition, given the uncertainty surrounding the concept of international organization generally. See Jan Klabbers, 'Unity, Diversity, Accountability: The Ambivalent Concept of International organization', (2013) 14 Melbourne Journal of International Law, 149-170.

${ }^{6}$ These elements are present in the definition contained in a number of conventions: see, e.g., the 2000 Palermo Convention on Organized Crime, article 2(j), as well as in the way US antitrust law defines the regional economic integration organization: see 15 USCS $§ 6211$.
} 
were at the time) were expected to pool their resources and grant the EEC exclusive competences to engage in trade relations with the outside world. If the EEC treaty was explicit on external trade powers, similar reasoning was applied to other fields as well, even where the Treaty did not explicitly grant such powers to the EEC, at the exclusion of the member states.

Most famously this occurred in the field of transport, where the Court of Justice made clear that the power to legislate internally (i.e., with respect to the six member states) necessarily entailed the power also to act externally: in foro interno, in foro externo. ${ }^{7}$ The precise setting in which the agreement at issue was concluded was not considered particularly relevant for purposes of internal EU consideration: the European Road Transport Agreement had been negotiated under the auspices of the UN's Economic Commission for Europe (UNECE), but this only affected the Court's reasoning in that the forum of UNECE triggered consideration of the provision of the EEC Treaty authorizing cooperation with and within international organizations but 'only by common action' of the member states. ${ }^{8}$

After the entry into force of the Lisbon Treaty, the most recent amendment of the EU treaties, it is clear that the EU has powers in external policy fields that are directly relevant to the United Nations treaty-making, such as trade and investment as well as environmental protection; maritime matters as well as transport matters; development as well as agriculture. In addition, the EU is explicitly empowered to act within a number of international organizations, including the UN family, but also covering entities such as the Organization for Economic Co-operation and Development and the Council for Europe. ${ }^{9}$ It is undisputed that the EU has external powers (and can thus, for instance, conclude treaties), but the precise division of powers inevitably reflects power struggles along two axes, which may come into play in the framework of multilateral treaty-making.

${ }^{7}$ See Case 22/70, Commission v Council (European Road Transport Agreement), ECLI:EU:C:1971:32.

${ }^{8}$ Ibid., paragraph 76.

${ }^{9}$ See Article 220 TFEU. 
On the one hand, there is the struggle between the Union and its member states: the latter may be reluctant to give up what they see as their sovereign prerogatives, whereas the Union may be keen to appropriate powers in order to do justice to what it holds to be its main raison d'être: ensure European integration.

In addition though, there is a second axis of trouble: the Union's institutions do not always see eye to eye. The Commission is the executive organ and supposed to represent the EU's common interest. This, in turn, may diverge from the interest as conceived by the member states (as represented in the Council and variations thereon, such as European Council) or the peoples of Europe, represented via direct elections in the European Parliament. And then there is the Court of Justice which sees itself as representing the law: it is the guardian of legality in the EU. It is by no means uncommon for the Council and the Commission to have diverging opinions, or for other vectors of disagreement among institutions to arise.

Either way, the precise boundaries between its powers and those of its member states remain disputed. The reason for this seems obvious: a power granted to the EU is a power abdicated by the member states. ${ }^{10}$ Put graphically, if the EU has an exclusive power to enter into fisheries conservation treaties with third states, this entails that France, or Germany, or any other of the (still) 28 member states of the EU, is barred from doing so - pre-empted, in Euro-jargon.

Hence, the scope of exclusive external powers is subject to a continuous struggle between the Union and its members: the EU is generally keen on centralization, the member states are generally keen on retaining their powers, even while realizing that pooling their resources may be more advantageous than going solo - acting as a single bloc prevents third parties (Russia, China, Japan, the US) from entertaining 'divide and rule' tactics. And this pattern is likely to repeat itself in

\footnotetext{
10 This, at least, is the generally accepted narrative, treating powers as a zerosum game. This seems rather too stylized though: it is possible for the EU to interfere with member state prerogatives while exercising its own proper powers, and vice versa. See further Jan Klabbers, 'Restraints on the TreatyMaking Powers of Member States deriving from EU Law', in Enzo Cannizzaro (ed.), The European Union as an Actor in International Relations (The Hague: Kluwer, 2002), 151-175.
} 
other regional economic integration organizations, as our political imagination is limited and we usually resort to mimicry when setting up new entities.

Where powers are supposed to be shared between the EU and its member states (as is the case with environmental protection), the site for struggle becomes the precise distribution of competences. In case of a shared competence, e.g., the question arises which part (EU or member states) is responsible for which aspect of a treaty under negotiation. If the treaty aims at creating a comprehensive regime, e.g., it may be the case that its putative provisions concerning one domain (e.g., on transboundary transportation of hazardous wastes) rests with the member states, whereas the provisions on another topic (say, conservation of marine resources) rests with the EU.

But even where it is clear that the EU's powers are exclusive, political struggle has not come to an end. The EU has exclusive powers in trade (including investment), fisheries conservation, and possibly anti-trust matters, but how key terms are defined determines the precise scope of those exclusive powers. The factor time adds another complication: upon the EU assuming exclusive competence, the member states can no longer conclude their own bilateral agreements with third parties anymore. ${ }^{11}$

\section{Conceptual Matters}

Like any other regional economic integration organization (but as noted, the EU is thus far the only recognized species of the genus), the EU can play a role in UN treaties (broadly conceived) in a variety of ways, and while the legal regimes may overlap, nonetheless it may be useful to distinguish various modes of participation.

First, there is full membership of the UN, or related organizations: the 'UN family' consists of some twenty international organizations that have entered into a relationship with the UN. These include several organizations with tasks which

\footnotetext{
11 In some of the Open Skies cases (concerning bilateral air traffic agreements concluded between various member states and the US), the Court of Justice rather quickly held that an amended treaty is to be regarded as a novel legal creation. See, e.g., case C-466/98, Commission v United Kingdom, ECLI:EU:C:2002:624.
} 
overlap with those of the EU, and one of them has allowed the EU to join: the Food and Agricultural Organization (FAO). It bears emphasizing that the EU is the only international organization currently in existence which is a member of a UN-affiliated organization. Membership of the UN itself and quite a few of the other specialized agencies is for the time being out of reach for international organizations: most specify that they are only open for membership by states ${ }^{12}$, and not even the EU is a state in any recognized meaning of that term..$^{13}$ Full membership entails the full panoply of rights (and obligations), including the right to participate in treaty-making under auspices of the organization concerned. This raises questions about the division of tasks and rights between the EU and its members that are independent members of the same organization. With respect to the $\mathrm{FAO}$, the basic principle is that when the EU participates in a vote, its member states do not, and if it is the EU participating, its amount of votes equals the number of its member states entitled to vote on the same issue. The matter is further governed by a 'declaration of competence' issued by the EU upon joining the FAO, as required under the FAO Constitution. ${ }^{14}$ Second, in organizations that reserve their membership to states, international organizations may be given observer status. The EU holds observer status with the UN (its General Assembly) as well as with most of the 'specialized agencies' (UN-related international organizations), including the most recent addition, the International Organization for Migration (IOM).

The precise details may differ from organization to organization, but generally, observers are allowed to participate in meetings and will be invited to attend diplomatic events both formal and informal (including cocktail parties), but may

\footnotetext{
12 With respect to the UN the International Court of Justice confirmed as much in an early opinion, without however paying too much attention to the precise contours of the requirement of statehood. See Conditions of Admission of a State to Membership in the United Nations (article 4 of the Charter), advisory opinion, [1948] ICJ Reports 57.

13 See Jan Klabbers, 'Sui Generis? The EU as an International Organization', in Dennis Patterson and Anna Södersten (eds.), A Companion to European Union Law and International Law (Chichester: Wiley, 2016), 3-15.

${ }^{14}$ For a brief overview, see Geert De Baere, 'EU Status in Other International Organizations', in Robert Schütze and Takis Tridimas (eds.), Oxford Principles of European Union Law. Volume I: The European Union Legal Order (Oxford University Press, 2018), 1234-1281, esp. 1255-1258. See also below.
} 
not table proposals or vote. ${ }^{15}$ With respect to the relationship between the UN and the EU, as much is laid down in a General Assembly resolution adopted in 2011, sketching some rights for the EU, but also explicitly stating that the EU representatives shall not have the right to vote, to co-sponsor resolutions or decisions, or to put forward candidates. The resolution was adopted with overwhelming support: 180 states in favour, with two abstentions (Syria and Zimbabwe) and some absentees. Nonetheless, Nauru voiced some (justifiable) concerns about how this helps to cement a privileged position for entities able to wield economic and political influence. ${ }^{16} \mathrm{Be}$ that as it may, often the EU will act on behalf of its member states during treaty negotiations, even where the EU itself only has observer status, and under EU law, the member states are under an obligation to coordinate their positions and represent the EU in other fora. This does not always work: sometimes political divisions between EU member states are simply too deep. But in order to harmonize positions treaty negotiations tend to be accompanied by EU 'coordination meetings', where the EU's member states decide what position to adopt and how to approach the matter at hand. These typically take place before multilateral negotiations commence (sometimes starting many months earlier) and continue in the margins of multilateral treaty negotiations: early in the morning and during weekends.

The status of observers is often said to follow from functional needs: they are coopted to the extent that they carry sufficient political weight to be instrumental in the solution or management of common issues. One curiosity about observer status is that in various organizations (including the International Maritime Organization and the World Intellectual Property Organization) observer status is held not by the EU but rather by one of its organs: the European Commission. This is curious because it would seem that the Commission lacks the required

15 The literature is in serious need of updating, with the most authoritative studies dating from the late 1970s and early 1980s. See Eric Suy, 'The Status of Observers in International Organizations', (1978) 160 Recueil des Cours, 75-179; Neri Sybesma-Knol, The Status of Observers in the United Nations (Brussels: Free University, 1981.

16 See UN Doc. A/RES/65/276 for the text of the resolution, while the debate is reported on at http://www.un.org/press/en/2011/ga11079.doc.htm (visited 20 January 2018). 
personality to be performing acts under international law and consequently, the treaty partner would be the EU rather than its Commission. ${ }^{17}$

A third way of participation by international organizations, including the EU, in UN settings is to participate in formal or informal groups, organizations, and networks set up by the UN. Perhaps the most eye-catching example of recent years is the Contact Group on Piracy of the Coast of Somalia, mentioned above. In addition, the EU sometimes concludes treaties with the UN or with UN programs or agencies: an example is the 2016 agreement with UNCTAD on cross-border trade in Central Africa. ${ }^{18}$

Fourth, where the EU is already a party to a multilateral treaty, it enjoys a relatively privileged position when it comes to the negotiation of further instruments or amendments. In particular, other international organizations willing and able to join still have a long process to accomplish; they still need to fight for a seat at the table, where the EU is already seated. And being already seated implies that often the EU has a voice in who else gets to be seated. Finally, it may be the case that international organizations participate in treaties concluded under auspices of the UN - it seems that this is, again, largely the sole preserve of the EU. Typically, the EU participates in environmental agreements and maritime agreements, as in these matters it has some generally recognized competences, while commodity agreements (which may, but need not be, negotiated under auspices of the UN or UNCTAD) would also affect the EU's competences. ${ }^{19}$ Still, the EU has also joined other regimes set up by the UN or UN-related agencies: it is a party, for instance, to the 2000 Palermo Convention

\footnotetext{
17 See case C-327/91, France v Commission, ECLI:EU:C:1994:305.

18 As reported at http://unctad.org/en/pages/newsdetails.aspx?OriginalVersionID=1356 (visited 20 January 2018).

${ }^{19}$ It has been reported that the 'EU and its member States' have taken active part in the negotiations leading to the Convention on the Rights of Persons with Disabilities, for instance, and the EU has also become a party to this Convention. On the other hand, in the same breath is mentioned the Enforced Disappearances convention which, however, is only open to member states of the UN. See Hadewych Hazelzet, 'The EU's Human Rights Policy in the UN: An Example of Effective Multilateralism?, in Jan Wouters et al. (eds.), The United Nations and the European Union: An Ever Stronger Partnership (The Hague: TMC Asser Institute, 2006), 183-194, at 187.
} 
on Organized Crime and all its protocols, the WHO Framework Convention on Tobacco, and even to a human rights convention: the Convention on the Rights of Persons with Disabilities.

The policy rationale is usually that the multilateral treaty concerned touches upon some aspect of EU competence: e.g., the WHO 2003 Framework Convention on Tobacco addresses, amongst other things, tobacco advertising, and this can have a bearing on the EU's internal market: different advertising rules across the EU's member states would potentially undermine the internal market. Likewise, treaties on cooperation in criminal matters, such as the 2003 Corruption Convention, will touch upon an EU competence: since the early 1990s the EU has the clear ambition of achieving cooperation and integration in the field of justice and cooperation in criminal matters. Much the same could be said for human rights treaties, but these tend to come with monitoring mechanisms that are often deemed incompatible with the role of the Court of Justice of the European Union as the ultimate guardian of legality within the EU. This perceived incompatibility has thwarted several attempts by the EU to join the European Convention on Human Rights ${ }^{20}$, but formed no obstacle to the EU joining the Convention on the Rights of Persons with Disabilities, as with respect to this convention the monitoring mechanism is provided in a separate protocol (to which the EU is not a party).

Hence, there are several possible forms in which the role of international organizations (in reality mostly the EU) within the UN and its family can play out. Adding the EU perspective, the picture becomes more complicated still. Partly this is because external agreements can relate to each of the three former pillars of the EU (economy, foreign policy, home affairs), which are subject to different procedures and dynamics, resulting from different sensitivities relating to sovereign prerogatives. In foreign policy, e.g., initiatives should emanate from the High Representative rather than from the Commission, and the role of the 
Court of Justice of the European Union (CJEU)over foreign policy issues is seriously limited when compared to its general role. ${ }^{21}$

\section{European Experiences}

The main practical issue arising with respect to the EU is often colloquially referred to as 'mixity', an intriguing technique for managing the co-existence of legal powers held by both the EU and its member states. Some have, somewhat charitably perhaps, heralded mixity as the EU's contribution to political theory as its own, uniquely European, version of quasi-federal doctrine; and while charitable, there is some truth to this. ${ }^{22}$

At the core of mixity is the idea that where competences are shared, both 'shareholders' ought to be involved. Agreements with third parties, in other words, ought to have 'mixed' participation of both the member states and the EU itself. This sounds easy and rather obvious, but it is not: many treaties, for instance, are only to open for participation by states, and since the EU is not a state, it cannot always participate.

This came to the fore already in the early 1970s, once the external commerce power had been transferred to the EU. It turned out that this demanded collective action within the General Agreement on Tariffs and Trade, but GATT did not provide for membership by an entity such as the EU. The Court found a pragmatic solution in a theory of succession, launched in International Fruit Company. ${ }^{23}$ It held that the EU was the successor to the rights and obligation of its member states under GATT, and posited three requirements for such a succession theory to apply. First, the member states must have intended to transfer powers to the EU; second, they must have actually transferred these

\footnotetext{
${ }^{21}$ See Article 275 TFEU; see Panos Koutrakos, 'Judicial Review in the EU's Common Foreign and Security Policy', (2018) 67 International and Comparative Law Quarterly, 1-35.

${ }^{22}$ See J.H.H. Weiler, 'The External Legal Relations of Non-unitary Actors: Mixity and the Federal Principle', reproduced in J.H.H. Weiler, The Constitution of Europe (Cambridge University Press, 1999), 130-187.

${ }^{23}$ See Cases 21-24/72, International Fruit Company v Produktschap voor Groenten en Fruit, ECLI:EU:C:1972:115.
} 
powers; and third, their treaty partners (in this case the other GATT parties) must have accepted the transfer. ${ }^{24}$

The succession theory is less appropriate in those fields where there can be legitimate doubt whether member states have intended to transfer powers or have actually transferred powers (and have done so irrevocably). Surely, such an argument is much more compelling in the field of commerce than it is in, say, security, or even transport. ${ }^{25}$ Note however that it was accepted, in first instance, in a well-known case involving United Nations sanctions, although the succession doctrine did not survive the appeals stage of the same case. ${ }^{26}$ The net result is that in some settings, the EU cannot join even if all its member states have joined an external regime; in such cases, the member states are under a strong duty of cooperation. ${ }^{27}$

The more common technique then is mixity, i.e. the joint participation of both the EU and its member states. ${ }^{28}$ The need to do so, as noted, arose when external agreements would cover topics that fell in part within the exclusive competence of the EU and in part within the exclusive competence of the member states, but this rationale has been expanded. Mixed treaties are concluded when competences are shared but not strictly delimited, and even when the subject matter falls solely within the powers of the EU. ${ }^{29}$ In the latter case, the justification is a practical one: involving all the member states is bound to

24 The Court engaged in a narrative from which these three requirements can be deduced.

${ }^{25}$ See, e.g., Case 308/06, Intertanko, ECLI:EU:C:2008:312.

${ }^{26}$ The doctrine was upheld by the EU's Court of First Instance in Case T-315/01, Kadi v Council and Commission, ECLI:EU:T:2005:332, paras. 193-203. On appeal, the CJEU effectively ignored the succession doctrine, reaching its conclusions via a different route. See Case C-402/05 P, Kadi v Council and Commission, ECLI:EU:C:2008:461.

${ }^{27}$ See Opinion 2/91 (ILO), ECLI:EU:C:1993:106.

28 Seminal is Joni Heliskoski, Mixed Agreements as a Technique for Organizing the International Relations of the European Community and it Member States (The Hague: Martinus Nijhoff, 2001); see also Christophe Hillion and Panos Koutrakos (eds.), Mixed Agreements Revisited: The EU and Its Member States in the World (Oxford: Hart, 2010).

${ }^{29}$ Not always though: the EU is a party to some treaties, especially commodity agreements, in the exercise of its exclusive powers. Examples include the 2007 International Coffee Agreement and the 2010 International Cocoa Agreement (not in force, but provisionally applied). 
enhance the legitimacy of the external agreement in the eyes of those member states, and this will help in faithful implementation. ${ }^{30}$

Since the obvious question arises about which part is ultimately responsible for implementation of which part of any external agreement, often regional economic integration organizations such as the EU are required to issue a declaration on the division of competences. The EU tends to be reluctant to be overly specific, for the (understandable) reason that a clear declaration on division of competences may come to have the effect of freezing that particular division: if the EU declares that the power to do X rests with the member states, it might pre-empt the possibility of the power to do $\mathrm{X}$ being transferred to the EU in the near future. ${ }^{31}$ As a result, such declarations tend to include the caveat that the current division of powers should not be seen as final - an example is the declaration attached to the instrument of confirmation of the Convention on the Rights of Persons with Disabilities which provides that the 'scope and exercise' of Union competence are 'by their nature, subject to continuous development...'.32

Technically, mixed agreements give rise to sometimes complicated or awkward issues. $^{33}$ One relatively straightforward issue relates to the question of signature: who gets to sign the treaty concerned? Obviously, in case both the EU and its member states are involved, all member states are expected to sign, as is the EU. The question remains though who is to sign on behalf of the EU. This depends on a Council decision, as the Council is authorized, under Article 216 TFEU, to decide on the issue. It may do so itself (mostly through the member state occupying the Presidency), or delegate it to the Commission or even,

\footnotetext{
30 The EU may have a bureaucratic apparatus, but it lacks its own customs officials, police officers, prison wardens et cetera; hence, for the implementation of the agreements to which it is a party, the EU strongly depends on its member states, acting, one might say, as organs of the EU.

31 Obviously, the reverse applies as well, but is generally considered to be less of a concern, if only because powers are often considered to be revocable by the member states. The classic study is Daniela Obradovic, 'Repatriation of Powers in the European Community', (1997) 34 Common Market Law Review, 59-88.

32 https://treaties.un.org/Pages/ViewDetails.aspx?src=TREATY\&mtdsg_no=IV$15 \&$ chapter $=4 \&$ clang=_en (visited 3 October 2017).

${ }^{33}$ Also during the life of a treaty: think of the making of reservations, the authority to interpret, or the facility of proposing amendments.
} 
hypothetically, to yet another member state. Even so, for internal legality purposes, the Council must adopt a decision approving the agreement in question - the agreement cannot be considered approved without such a decision. As a corollary, when the validity of the agreement is later contested, all that can be done internally is that the Council decision approving it is invalidated - the EU cannot, on its own, declare an agreement concluded with third parties invalid.

In most cases, there is an additional complication in that the Council can approve external agreements only with the consent of the European Parliament, or having consulted the European Parliament. Parliament's consent is required for several classes of agreements, including association agreements or other agreements setting up an institutional framework, including those negotiated under UN auspices. In most other cases it needs to be consulted, with the exception of foreign policy agreements. ${ }^{34}$

Two additional issues stand out, none of them seemingly spectacular or of great legal import but both of them of the utmost practical - and political - relevance. The first relates to the negotiating position: with a couple of interested institutions (Council, Commission and Parliament) and 28 member states, it is by no means self-evident what position the EU shall take, and how it shall try to give effect to its position. The TFEU does not offer much guidance beyond suggesting that the matter of treaty negotiations is formally in the hands of the Council. ${ }^{35}$ And yet, a number of practical issues need to be discussed beforehand, including the question what kind of agreement will be negotiated. Typically, the Council will work on the basis of a recommendation stemming from the Commission (or, if the matter relates mostly to security, from the High Representative of the Union for Foreign Affairs and Security Policy), outlining why the topic is relevant, what the Union's interest is, and how it is best approached from an EU perspective. Once this is done, the Council can decide to allow the Commission to enter into negotiations, designate the Commission as the main negotiator, and present it with the negotiation directives.

\footnotetext{
34 See Article 218 TFEU.

35 A separate procedure relates to trade agreements, under Article 207 TFEU.
} 
All of this breaks down into a number of more detailed questions. To what extent is EU competence involved? Is the EU itself even allowed, under the rules of the relevant international organization, to participate in the negotiations and if so, can it do so as full participant or only as observer? In the latter case, after all, it may not be allowed to vote (and thus needs to rely on its member states toeing the line), and may not even have a seat at the main negotiating table. More to the point, usually with mixed agreements issues within EU competence shall be left to the Commission, with the Council Presidency (which rotates among member states every six months) representing member state competences - it is thus convenient if Commission and Presidency can be seated in close proximity. ${ }^{36}$

\section{On the Receiving End}

As a theoretical matter, international organizations can only act within other international organizations if and when they are allowed to act: third parties are under no obligation to recognize their existence, and are under no obligation to facilitate internal processes within some organization or other by collaborating in its external relations. It follows that, if and when treaties are only open for participation by states, organizations have no role to play unless the putative treaty partners allow this. This starting point seems to be generally accepted: it already underpinned the 'succession theory' launched by the CJEU in International Fruit Company.

In this light, it is perhaps surprising how willing third parties, both within and without the UN, have been to accommodate the EU, even though functionally much of this makes sense. Clearly, since the EU exercises powers on a number of issues (sometimes excluding member state powers), there is a functional reason to facilitate cooperation with it.

In some cases, cooperation warrants amendment of constituent documents. The FAO, as is well-known, changed its Constitution in order to allow the EU to join it.

\footnotetext{
${ }^{36}$ Much of this is culled from Hillion and Koutrakos (eds.), Mixed Agreements Revisited; see also Pieter Jan Kuijper et al. (eds.), The Law of EU External Relations: Cases, Materials, and Commentary on the EU as an International Legal Actor (Oxford University Press, 2013), esp. 69-75.
} 
Originally only open to 'nations'37, and allowing international organizations on the basis of an observer-type status but without the right to vote ${ }^{38}$, in the early 1990s the FAO constitution was amended so as to facilitate membership of regional economic integration organizations, meaning the EU. Several conditions must be met though: such an organization must be composed of states; a majority of its member states must also be members of the FAO, and it must have competence over matters within the purview of the FAO. ${ }^{39}$

This does not exhaust the matter, as the joint membership of both the EU and its member states raises a number of practical issues, ranging from speaking and voting rights and membership of subsidiary organs to such things as budgetary assessments. As mentioned, within the FAO, careful delimitations have been put in place. Article II FAO specifies, in paragraphs 5-7, that regional economic integration organizations need to submitted declarations of competence of the sort discussed above; that they shall announce changes in the division of competences, and that the default presumption is that competences are presumed to have been retained by member states unless otherwise notified or informed.

Membership rights, so paragraph 8 of Article II continues, shall be exercised on an 'alternative basis' between the EU and its member states in their respective spheres of competence, and the EU can participate in meetings and organs of the FAO within its competences, except in organs of limited membership. Voting too relates to the division of competences: where the EU is competent, it can vote but then its member states cannot - and vice versa. ${ }^{40}$ For the time being, the FAO is the only organization in the UN family of which the EU is a member, indeed, to which any international organization is a member. ${ }^{41}$ Organizations play a role in

\footnotetext{
${ }^{37}$ Article II, paragraph 2 FAO. This is rare, and potentially risky, in that states and nations need not (indeed, often are not) identical. Some treaties are only open to 'governments', which is also rare and perhaps a tad inaccurate, as governments tend to represent states. An example is the 1946 International Whaling Convention.

${ }^{38}$ Article II, paragraph 5 FAO (old).

${ }^{39}$ Article II, paragraph 4 FAO (as amended).

${ }^{40}$ Article II(10) FAO.

41 The EU is a founding member of the World Trade Organization, but the WTO is not considered a member of the UN family.
} 
other UN-related organizations, whether as observer or otherwise, but falling short of membership.

Other conventions have imagined different mechanisms to accommodate regional economic integration organizations. Such organizations are, for instance, allowed to become a party to the 1992 UN Framework Convention on Climate Change, but if they do and none of their member states also join, then they shall be bound by all the obligations under the Convention. ${ }^{42}$ In other words, any possibly internally existing division of competences shall be ignored. This is, however, a highly unlikely scenario; the more likely scenario is that of joint or mixed membership, in which case the regional economic integration organization concerned shall issue a declaration on the division of competences, as discussed above with respect to the EU.

Even when not formal members, international organizations may and do exercise influence on treaty-making processes ${ }^{43}$, and for good reason. After all, often enough international organizations possess a broad knowledge base, typically the sort of expertise that may be of assistance when negotiating a multilateral treaty on a particular topic associated with the common good, and it is typically on such topics that agreements are concluded under UN auspices. An example, still ongoing, relates to the conclusion of a convention on marine biodiversity in areas beyond national jurisdiction. Here, an informal working group laying much of the groundwork included 'permanent observers' such as the EU, the Caribbean Community, the Asian-African Legal Consultative Organization, and Pacific Islands Forum ${ }^{44}$, as well as a number of specialized agencies (FAO, WIPO, International Seabed Authority, and UNESCO) and other organizations with an ad hoc participant status, such as various regional fisheries commissions. Given the substance matter of the agreement under

\footnotetext{
42 See article 22 UN Framework Convention on Climate Change.

43 The EU proudly boasts that a 2017 IMO agreement to improve safety of passenger ships owes much to the work of the EU and its European Maritime Safety Agency: see https://ec.europa.eu/transport/modes/maritime/news/2017-06-16-maritimetransport-commission-welcomes-international-agreement_en (visited 20 January 2018).

${ }^{44}$ Also mentioned is the International Union for the Conservation of Nature, but it is unclear whether this qualifies as an intergovernmental organization.
} 
preparation (a convention addressing biodiversity in maritime areas beyond national jurisdiction, dealing with conservation but also with possible industrial applications of natural resources and the intellectual property implications thereof), all of these can be considered stakeholders in a relevant sense, boasting specific expertise or having a specific interest. ${ }^{45}$

While the precise prerogatives of such participating organizations may differ in different contexts, having a seat at the table well-nigh guarantees possibilities for exercising at least a modest degree of influence, both by means of taking the floor and (possibly of greater practical relevance) by lobbying the national delegations, bringing matters to their attention, and generally bringing their expertise to bear on the matter.

\section{To Conclude}

The position of international organizations within other organizations has thus far rarely been studied ${ }^{46}$, and practical examples are few and far between. Much the same applies to practices of treaty participation: it is generally acknowledged that the EU participates in treaties ${ }^{47}$, but with respect to other organizations, far less is known. It is sobering to realize perhaps that the leading study on the UN's treaty practice dates back to the $1950 \mathrm{~s}^{48}$, and that there is no comprehensive study available of the legal aspects of treaty-making within the UN. The General

45 The composition can be found at http://www.un.org/Depts/los/biodiversityworkinggroup/documents/participa nts_wg9.pdf (visited 20 January 2018). Most of these are also participating in the work of the Preparatory Commission advising the General Assembly on elements of a convention: see http://www.un.org/depts/los/biodiversity/prepcom_files/Final_List_of_Particip ants_BBNJ_IV_Jan_2018.pdf (visited 20 January 2018). ${ }^{46} \mathrm{~A}$ pioneering monograph, now largely outdated, is Rachel Frid, The Relations between the EC and International Organizations: Legal Theory and Practice (The Hague: Kluwer, 1995).

${ }^{47}$ For an overview, see Delano Verwey, The European Community, the European Union and the International Law of Treaties (The Hague: TMC Asser Instituut, 2004).

${ }^{48}$ See Shabtai Rosenne, 'United Nations Treaty Practice', (1954) 86 Recueil des Cours, 275-444. 
Assembly reviewed the multilateral treaty-making process, but did so as long ago as the late 1970 s and early 1980 s.

The treaty practice of the EU, in all its diverse aspects, has inspired a number indepth studies over the years. By contrast, its membership of international organizations has been less popular as a research topic, and relations between international organizations generally inter se is only starting to be recognized as a proper topic for further study and reflection, and much the same applies to the position of the EU in UN-sponsored treaty negotiations. These are topics of great practical and political significance, not least with a view to the lessons any future regional economic integration may learn. They are also, however, of great theoretical relevance: the more organizations interact with each other, the more they must be seen as autonomously operating entities. And this, in turn, suggests they can no longer accurately be portrayed as merely exercising powers delegated by their member states. Any novel way of thinking about international organizations must probably reserve some role for delegation (this, after all, is how organizations come into being), but should not hesitate to look beyond delegation as well. This is a lesson the EU teaches us in its own right, and a lesson taught even more strongly when considering the relationship between the EU and the UN and the EU's role in UN treaty-making processes. 